\title{
DINAMIKA MADRASAH DAN PRANATA SOSIAL
}

\author{
BASINUN
}

\begin{abstract}
Islamic education is a social problem, so that in its institutions can not be separated from existing social institutions. Education is one of the functions that must be carried out with the best by families, communities, and the government in an integrated manner to develop the function of education. Madrasah as a social institution is an educational institution that is characterized by Islam that has unique characteristics.
\end{abstract}

Kata Kunci: Madrasah, Pranata Sosial.

\section{A. Pendahuluan}

Era otonomi pendidikan memberikan peluang besar bagi perbaikan tata kelola madrasah melalui peningkatan partisipasi masyarakat.Namun demikian nampaknya madrasah belum sepenuhnya mampu memaksimalkan peluang tersebut.Problem kurangnya kemitraan dialami oleh masyarakat pengelola madrasah.Madrasah kurang mampu mendinamisasi partisipasi masyakarat setempat agar ada rasa kepedulian dalam mengembangkan dan memajukan madrasah. Padahal dengan adanya partisipasi masyarakat diharapkan kualitas, akuntabilitas, relevansi program-program pendidikan yang didesain dan diselenggarakan oleh madrasah dapat dirasakan manfaatnya oleh masyarakat. Sesungguhnya pendidikan adalah masalah besar dan sangat penting yang aktual sepanjang zaman, karena pendidikan orang dapat menjadi maju, dengan bekal ilmu pengetahuan dan teknologi manusia mampu mengolah alam yang di karuniai oleh sang pencipta yaitu Allah SWT kepada insan di dunia, setiap insan dianjurkan untuk terus belajar dari ayunan hingga ke liang lahad. 
Berbicara mengenai pendidikan Islam tentulah sangat luas yaitu baik pendidikan dari ruang maupun waktu, adapun pendidikan yang di peroleh di dunia ini melalui pendidikan formal, informal dan non formal. Bertitik tolak dari itu seperti yang kita ketahui perkembangan pendidikan Islam di Indonesia yang penuh dengan sekelumit persoalan dalam keberadaan di kancah persaingan globalisasi yang semakin pesat.Hal yang membuka sudut pandang para pemikir pendidikan Islam mengalami perkembangan yang tidak hanya larut dengan tuntutan keagamaan karena seseorang yang hidup di dunia harus mampu memberikan peran pada alam hidupnya. Pendidikan Islam adalah termasuk masalah sosial, sehingga dalam kelembagaannya tidak terlepas dari lembaga-lembaga sosial yang ada.

Lembaga disebut juga institusi atau pranata, sedangkan lembaga sosial adalah suatu bentuk organisasi yang tersusun relatif tetap atas polapola tingkah laku, peranan dan relasi-relasi yang terarah dalam mengikat individu yang mempunyai otoritas formal dan sanksi hukum, guna tercapainya kebutuhan-kebutuhan sosial dasar.

\section{B. Pembahasan}

1. PEngertian Madrasah

Kata "madrasah" dalam bahasa Arab adalah bentuk kata keterangan tempat (zharaf makan) dari akar kata "darasa".Secara harfiah "madrasah" diartikan sebagai "tempat belajar para pelajar", atau "tempat untuk memberikan pelajaran".Madrasah merupakan isim makna dari kata darasa yang berarti tempat duduk untuk belajar.Istilah madrasah ini sekarang telah menyatu dengan istilah sekolah atau perguruan (terutama perguruan Islam).Karenanya istilah madrasah tidak hanya diartikan sekolah dalam arti sempit tetapi juga bisa dimaknai rumah, istana, kuttab, 
perpustakaan, surau, masjid, dan lain-lain.Bahkan juga seorang ibu bisa dikatakan sebagai madrasah pemula. (Dakir, 2009)

Lembaga pendidikan madrasah telah di kenal di timur tengah hanya saja pendidikan pada saat itu sebagai pendidikan keilmuan tingkat tinggi, Pada abad 11-12 M Wazir Bani Saljuk, Nizam al-Mulk mendirikan madrasah Nizamiyah di Bagdad sebuah pendidikan yang bertujuan memperkaya khazanah lembaga pendidikan di masyarakat Islam(Indra Hasbi, 1995: 205). Menurut George Makdisi yang di kutip oleh Ainurrafiq bahwa akar sejarah pertumbuhan madrasah dalam dunia Islam berawal dari masjid pada abad ke 8-9, awal perkembangan madrasah karena pemerintahan memiliki andil yang cukup besar seperti Nidzam al-Mulk 1063 M, Nur al-Din Zanky 1146-1174 M dsb. Dan perhatian yang besar dari para saudagar, ulama, dan elemen masyarakat lainnya.Disini jelas terlihat antara fihak pemerintah dan swasta bekerja sama dalam melakukan perkembangan madrasah sehingga madrasah menjadi sebuah lembaga pendidikan yang maju dan berkembang adalah sesuatu yang sangat utopis, inilah awal mulanya sejarah perkembangan madrasah di dunia Islam. Berbeda halnya jika di dalam negeri madrasah adalah pendidikan yang memberikan pengajaran Islam pada tingkat rendah dan menengah.

2. DinAmika Madrasah sebagai PENdidikan Berbasis MASYARAKAT

Menurut Muhaimin (2005: 186) dilihat dari sisi historitasnya terdapat dua faktor yang mempengaruhi lahirnya madrasah di Indonesia, yaitu, pertama, adanya pandangan yang mengatakan bahwa sistem pendidikan Islam tradisional dirasakan kurang bisa memenuhi kebutuhan pragmatis masyarakat; kedua, adanya kekuatiran atas cepatnya perkembangan persekolahan Belanda yang akan menimbulkan pemikiran 
sekuler di masyarakat. Untuk menyeimbangkan perkembangan sekulerisme maka masyarakat muslim melakukan reformasi melalui upaya pengembangan pendidikan dan pemberdayaan madrasah.

Pendapat tersebut di atas dikuatkan oleh Azyumardi Azra (2000: 99) bahwa madrasah di Indonesia lahir sebagai bentuk modernisasi sistem pendidikan Islam yang tradisional. Faktor pendorong lahirnya gerakan ini adalah adanya ekspansi pemerintahan kolonial Belanda dan Kristen. Dalam konteks ini ditemukan adanya Sekolah Diniyyah Zainuddin Labay al-Yunusi, Sumatra Thawalib, madrasah yang didirikan al-Jami'atul Khairiyyah dan kemudian juga madrasah-madrasah yang didirikan oleh al-Irsyad.

Melihat fakta sejarah tersebut di atas, kebijakan tentang desentralisasi pendidikan sebenarnya bukan hal yang asing bagi madrasah. Terlebih banyak madrasah yang lahir dan tumbuh dari inisiatif masyarakat sendiri (H.A.R. Tilaar, 2004: 152). Masyarakat dalam hal ini, baik individu maupun organisasi membangun madrasah untuk memenuhi kebutuhan kebutuhan pendidikan mereka. Tidak mengherankan apabila madrasah yang dibangun oleh masyarakat bisa seadanya saja atau memakai tempat apa adanya. Mereka didorong oleh semangat keagamaan dan dakwah untuk mencari ilmu dan mengamalkan ajaran agama Islam. Hingga saat ini tidak mengherankan apabila jumlah madrasah yang ada di Indonesia kurang lebih 90\% milik swasta sedangkan sisanya berstatus negeri (Muhaimin, 2005: 185).

Apabila dewasa ini diskursus pendidikan nasional mewacanakan pentingnya inovasi pendidikan nasional untuk melahirkan pendidikan yang dikelola masyarakat community-based management (CBM) maka pesantren sebagai induk semangnya madrasah merupakan model yang archaic. Namun tentu prinsip-prinsip manajemen modern perlu diterapkan di dalam pola pendidikan yang berdasarkan manajemen 
masyarakat. Pada akhirnya community-based management dari pendidikan akan bermuara kepada manajemen sekolah (school-based management) atau manajemen madrasah yang berarti pengelolaan lembaga pendidikan madrasah adalah pengelolaan yang otonom yang mengimplementasikan aktivitas dan kreativitas para pengelolanya baik kepala sekolah maupun para gurunya di dalam melaksanakan misi sekolah. Tentu CBM dan SBM menuntut para pengelola yang mempunyai pandangan yang luas serta menguasai teknikteknik manajemen modern, termasuk manajemen sekolah.

\section{Perkembangan Madrasah}

Perubahan ke madrasah dari pendidikan pesantren dan sekolah yaitu sekolah umum yang bercirikan Islam dengan cakupan tanggung jawab: a) sebagai lembaga pencerdasan kehidupan masyarakat Indonesia umumnya, khususnya masyarakat islami, b) sebagai lembaga pelestarian budaya keislaman bagi masyarakat Indonesia dan sebagai lembaga pelopor bagi peningkatan kualitas masyarakat Indonesia dan muslim khususnya( Syarifudin, 2005: 209).

Madrasah dikelola oleh Kementerian Agama, setelah kemerdekaan bangsa Indonesia mengupayakan untuk menjembantani kensenjangan antara model pendidikan sekolah dengan pesantren, jika melihat sejarah madrasah yang sangat di dukung oleh pemerintah dan bangsawan berbeda halnya dengan Indonesia yang kurang memperhatikannya namun terdapat sedikit celah perhatian pemerintah pada tahun 1975 munculnya Surat keputusan Bersama (SKB) 3 Menteri yang terdiri dari menteri agama, pendidikan dan kebudayaan serta dalam negeri yang memuat materi pelajaran pada madrasah $70 \%$ umum dan $30 \%$ agama, Steenbrink beranggapan bahwa membuat kerugian terhadap madrasah. Namun jika meneropong dari sudut dikotomi sangat positif dengan 
adanya SKB 3 menteri ini antara ilmu agama dengan ilmu umum(Assifudin, A Janah, 2010 :170).

Madrasah memiliki kurikulum, metode dan cara mengajar sendiri yang berbeda dengan sekolah. Meskipun mengajarkan ilmu pengetahuan umum sebagaimana yang diajarkan di sekolah, madrasah memiliki karakter tersendiri, yaitu sangat menonjolkan nilai religiusitas masyarakatnya, tidak hanya itu madrasah merupakan pengembangan dari pesantren yang sudah memasukkan materi pelajaran umum.Materi pelajaran yang diberikan disesuaikan dengan tingkat kecerdasan murid, dimulai dengan pelajaran yang mudah terus dilanjutkan secara berangsur sampai selesai tingkat pengetahuan dasar.Cara penyajian juga sudah disusun sedemikian sehingga mudah dipahami oleh anak-anak. Kurikulum pada bidang studi agama Islam di bagi kepada beberapa sub yaitu fiqh, akidah Akhlak, al-Qur-an Hadis, sejarah kebudayaan Islam. Didalam budaya sekolah, siswi memakai jilbab dan siswa memakai celana panjang, pada proses pembelajaran berlangsung siswa membaca doa dan ketika memulai dan mengakhiri pembelajaran mengucapkan salam. Subtansi perubahan kebijakan madrasah dari sekolah mengkhususkan diri pada kajian agama islam dalam rangka mengarahkan, membimbing, membina dan melahirkan pendidikan madrasah yang qualified mampu mengembangkan kognitif, akfektif dan psikomotor.

Pada kepemimpinan pendidikan modern, perlu memperhatikan hal-hal pokok yang harus di miliki, yaitu : 1) visioner, mempunyai wawasan luas dan matang sehingga mampu merumuskan visi dan misi serta selalu bertindak proaktif dalam mengikuti perkembangan dan dinamisasi program pendidikan dalam kehidupan. 2) pemersatu, mampu mempersatukan semua unsur dan potensi yang berbeda-beda disuatu lembaga pendidikan sehingga menjadi kekuatan sinergi hingga bermanfaat bagi semua pihak. 3) pemberdaya, pemimpin ialah seorang 
motivator, pendorong, suka menolong orang lain, dalam diri pemimpin terccermin pribadi yang demokrat, inklusif, deligatif dan komunikatif, empatif dan responsif. 4) pengendalian emosional yang tidak hanya pada akal tetapi juga hati, 5) integritas yang harus taat pada prinsip moral dan hukum dalam semua aspek kehidupan termasuk kehidupan akademik(Assifudin A Janah, 2010: 78).Disini jelas tampak bahwa peran madrasah sangat srategis terhadap pendidikan Islam di Indonesia karena sebagai wadah berkumpulnya pendidikan umum dengan pendidikan keagamaan Islam hingga mampu mencetak kader yang intelektual tinggi berbasis keislaman.Yang diharapkan dapat menjadi khalifah yang sempurna di muka bumi ini, walaupun tidak di pungkiri perhatian masyarakat dan pemerintah terhadap madrasah masih minim.

\section{MadRasaH dan Fungsinya}

Pendidikan merupakan salah satu fungsi yang harus dilakukan dengan sebaik- baiknya oleh keluarga, masyarakat, dan pemerintah secara terpadu untuk mengembangkan fungsi pendidikan. Kualitas pendidikan bukan hanya dilihat dari kualitas individu, melainkan juga berkaitan erat dengan kualitas kehidupan masyarakat, berbangsa dan bernegara.Dalam bukunya Abdullah Idi (2011) Jalaludin mengatakan, manusia sebagai mahluk sosial memerlukan pendidikan khusus.Pendidikan khusus itu diarahkan kepada usaha membimbing dan pengembangan potensi manusia agar serasi dengan lingkungan sosialnya. Berdasarkan ruang lingkup sosial tersebut perlu dirumuskan pendidikan khusus, dengan konsep perumusannya: (1) pendidikan keluarga; (2) pendidikan kelembagaan yang terdiri atas: (a) kelembagaan formal seperti madrasah ataupun pesantren hingga kejenjang perguruan tinggi; dan (b) kelembagaan non formal, seperti majlis ta'lim, baik di masjid maupun majlis lainnya. 1) Pranata Pendidikan Pranata pendidikan merupakan 
salah satu pranata yang penting dalam masyarakat, karena merupakan salah satu wadah nilai-nilai yang ideal dalam masyarakat.Secara historis pendidikan sudah ada sejak manusia ada di muka bumi ini.

Fungsi pendidikan di sekolah selanjutnya sedikit banyak dipengaruhi oleh corak pengalaman seseorang di lingkungan masyarakat. Pranata Pendidikan memiliki beberapa fungsi sebagai berikut:

a. Mempersiapkan anggota masyarakat untuk mencari nafkah.

b. Mengembangkan bakat perorangan demi kepuasan pribadi.

c. Melestarikan kebudayaan serta berbagai transmisi kebudayaan masyarakat.

d. Mengurangi pengendalian orang tua melalui sekolah. e. Memperpanjang masa remaja, karena kedewasaan anak terhambat sebab secara ekonomi masih menggantungkan orang tua

e. Mobilitas sistem kelas sosial, melalui sekolah dapat menjadi saluran mobilitas sosial bagi siswa ke status yang lebih tinggi.

\section{KESIMPULAN}

Madrasah sebagai pranata sosial merupakan lembaga pendidikan yang berciri khas agama Islam mempunyai karakteristik yang unik. Mayoritas madrasah lahir dari prakarsa masyarakat di mana madrasah tersebut lahir.Karena dilahirkan dari masyarakat maka kualitas madrasah menjadi beragam.Madrasah yang didukung oleh masyarakat yang secara sosio-ekonomi dan cultural memadai, maka dapat berkembang dengan baik. Sebaliknya madrasah yang tidak didukung oleh masyarakat yang mempunyai modal sosial yang kuat akan mengalami masalah. Oleh sebab itu, menjadi penting untuk mencari alternatif, bagaimana agar mayoritas madrasah yang lahir dari masyarakat yang secara sosial-ekonomi kurang memadai dapat tumbuh berkembang dengan baik, sehingga mutu 
pendidikannya dapat memenuhi keinginan masyarakat pengguna jasa layanan pendidikan. Maka dari itu, pemberdayaan madrasah sangat diperlukan, terutama dalam mengelola sumberdaya manusia yang tersedia dan sumber daya yang ada di sekitarnya

Penulis : Basinun, M.Pd adalah Dosen Tetap pada Fakultas Tarbiyah dan Tadris IAIN Bengkulu

\section{DAFTAR PUSTAKA}

Ahmad Janan Asifuddin, Mengungkit Pilar-Pilar Pendidikan Islam, Yogyakarta: SUKA -Press UIN Sunan Kalijaga, 2010

Alfauzan Amin.Madrasah dan Pranata Sosial. Jurnal At Ta'lim IAIN Bengkulu. 2017

Ardiwinata, S. Jajat. dkk. 2008. Sosiologi Antropologi Pendidikan. Bandung: UPI Press

Azra, Azyumardi, Pendidikan Islam; tradisi dan modernisasi menuju millennium baru, (Ciputat: Logos, 2000)

Direktorat Jenderal Pendidikan Islam Kementrian Agama RI, Peningkatan Manajemen MelauiPenguatan Tata Kelola dan Akuntabilitas di Sekolah/ Madrasah (Jakarta: BOS, 2011)

Hermawan, Ruswandi.dkk. 2006. Perkembangan Masyarakat dan Budaya.Bandung : UPI Press.

Kotter, John. P \& Cohen, S..The heart of change.(Deloitte consulting LLC, 2002)

Mahfud, Sahal, Dinamika pesantren dan madrasah. (Yogyakarta: Pustaka Pelajar, 2002) Mastuhu.Memberdayakan sistem pendidikan Islam.(Ciputat: Logos, 1999) 
Muhaimin, Wacana pengembangan pendidikan Islam.(Yogyakarta: Pustaka Pelajar, 2004)

Pengembangan kurikulum agama Islam di sekolah, madrasah dan perguruan tinggi.(Jakarta: Rajawali Pers, 2005)

Mustafa, Sejarah Pendidikan Islam di Indonesia, (Bandung: Pustaka Setia, 1999)

Nuryatno, Agus, Mazhab Pendidikan Kritis (Yogyakarta: Resist Book, 2008)

Pranarka \& Moeljarto, Vidhyandika.Pemberdayaan (empowering).(Jakarta: CSIS, 1996)

Rohman, Arif.dkk. 2003. Sosiologi. Klaten : PT Intan Prawira.

Rosyada, Dede. Paradigma pendidikan demokratis: Sebuah model pelibatan masyarakat dalam penyelenggaraan pendidikan.( Jakarta: Kencana, 2007)

Rukandi, Kanda.dkk. 2006. Perspektif Sosial Budaya. Bandung : UPI Press.

Suharto, Edi. Membangun masyarakat memberdayakan rakyat: Kajian strategis pembangunan kesejahteraan sosialE pekerjaan sosial. (Bandung: Refika Aditama, 2009)

Tilaar, H.A.R. Membenahi Pendidikan Nasional ( Bandung: Rineka Cipta, 2009) 2004)

Paradigma Baru Pendidikan Nasional (Bandung: Rineka Cipta, 